\title{
Microalgae: Potential for Bioeconomy in Food Systems
}

\author{
Elwi Machado Sierra, María C. Serrano (D), Anderson Manares (D), Abraham Guerra and Yani Aranguren Díaz *(D) \\ Department of Scientific Research, Development and Innovation in Microbiology, Universidad Simón Bolívar, \\ Barranquilla 080002, Colombia; elwi.machado@unisimonbolivar.edu (E.M.S.); mary.csh98@gmail.com (M.C.S.); \\ anderson.manares@unisimon.edu.co (A.M.); abraham.guerra@unisimon.edu.co (A.G.) \\ * Correspondence: yani.aranguren@unisimonbolivar.edu.co
}

check for

updates

Citation: Machado Sierra, E.; Serrano, M.C.; Manares, A.; Guerra, A.; Aranguren Díaz, Y. Microalgae: Potential for Bioeconomy in Food Systems. Appl. Sci. 2021, 11, 11316. https://doi.org/10.3390/ app112311316

\section{Academic Editors:}

Wojciech Kolanowski and Anna Gramza-Michałowska

Received: 2 November 2021 Accepted: 16 November 2021 Published: 29 November 2021

Publisher's Note: MDPI stays neutral with regard to jurisdictional claims in published maps and institutional affiliations.

Copyright: (c) 2021 by the authors. Licensee MDPI, Basel, Switzerland. This article is an open access article distributed under the terms and conditions of the Creative Commons Attribution (CC BY) license (https:/ / creativecommons.org/licenses/by/ $4.0 /)$.

\begin{abstract}
The efficient use of natural resources is essential for the planet's sustainability and ensuring food security. Colombia's large availability of water resources in combination with its climatic characteristics allows for the development of many microalgae species. The use of microalgae can potentially contribute to sustainable production in support of the agri-food sector. The nutritional composition (proteins, carbohydrates, fatty acids, vitamins, pigments, and antioxidants) of microalgae along with the ease of producing high biomass yields make them an excellent choice for human and animal nutrition and agriculture. Several species of microalgae have been studied seeking to develop food supplements for pigs, ruminants, poultry, fish, crustaceans, rabbits, and even bees. Important benefits to animal health, production, and improved bromatological and organoleptic characteristics of milk, meat, and eggs have been observed. Based on the functional properties of some microalgae species, foods and supplements have also been developed for human nutrition. Moreover, because microalgae contain essential nutrients, they can be utilized as biofertilizers by replacing chemical fertilizers, which are detrimental to the environment. In view of the above, the study of microalgae is a promising research area for the development of biotechnology and bioeconomy in Colombia.
\end{abstract}

Keywords: animal nutrition; biofertilizers; Colombia; functional foods; sustainability

\section{Introduction}

Colombia has five large continental hydrological zones and numerous rivers, including the Magdalena, Putumayo, and Cauca [1]. Within these zones, six units comprise approximately 1900 swamps and wetlands, of which $80 \%$ are located in the Caribbean region [2]. It also has marine and oceanic waters, with two coastlines spanning $1642 \mathrm{~km}$ in the Caribbean and $1300 \mathrm{~km}$ in the Pacific [3]. The climatic, orographic, and hydrological characteristics allow for the existence of numerous ecosystems and appreciable biodiversity, which makes Colombia a megadiverse country [4]. Together, these natural resources offer the potential for biotechnological development, sustainable use, and growth of the bioeconomy in the country.

Paradoxically, 27\% of Colombian ecosystems are at critical risk and $17 \%$ are at risk in terms of biodiversity, ecosystem services, and social welfare [5]. In addition, poverty has historically been a social problem, and in the last 10 years, 34.7-42.5\% of Colombians have been classified as poor [6]. In this regard, conservation of biodiversity is essential for facing economic, social, and climatic problems.

Bioeconomy integrates science, society, economy, industry, and environment for sustainable development [7]. It aims at satisfying the needs of individuals in the agri-food and energy sectors mainly, in balance with the environment [8]. Since the implementation of the United Nations 2030 Agenda, bioeconomy has been fostered in Latin America as a commitment to sustainable development [9]. In Colombia, the green growth policy focuses on technological development and boosting economic productivity on the basis of environmental sustainability and social inclusion [10].

Microalgae are aquatic microorganisms [11] that are an important source of biomass in food chains [11-13]. These microorganisms contain chloroplasts or photosynthetic cell 
structures, and phycobiliproteins such as chlorophylls and carotenoids $[11,14,15]$. The estimated number of microalgae species ranges from 200,000 to several million [11,16]. Many species are used in agriculture, food, bioremediation, biological control, $\mathrm{CO}_{2}$ fixation, and alternative energy production [17-20].

Microalgae are widely distributed in a variety of aquatic and terrestrial environments; they are part of the plankton and play a major role in ecosystems. Approximately half of the planet's photosynthesis and oxygen production can be attributed to microalgae, which makes them essential for carbon fixation [12,13,21].

Considering the abundance of hydric resources and ecosystems, a high diversity of microalgae is expected in Colombia. Nevertheless, microalgae and their applications have been poorly studied in the country. Therefore, there is considerable potential in Colombia for the development of biotechnology and bioeconomy using microalgae, which are necessary for agri-food security. This review discusses some applications of microalgae biomass that could be developed in Colombia.

\section{Biodiversity}

Microalgae are a highly diverse group that includes prokaryotes (cyanobacteria) and photosynthetic eukaryotes belonging to three kingdoms: Protozoa, Chromista, and Plantae $[11,22]$. The classification of microalgae has been based on morphological, physiological, and ecological features. Recently, molecular and ultrastructural characteristics have been included in this classification [23]. Due to the differences between the classification systems for prokaryotes (International Code of Nomenclature of Prokaryotes) and those for eukaryotes, such as the International Code of Nomenclature for algae, fungi and plants, many authors exclude cyanobacteria from the microalgae group. Nevertheless, one prokaryotic lineage is usually identified within the group, Cyanophyta (bluegreen algae); and nine eukaryotes: Prochlorophyta, Glaucophyta, Rhodophyta (red algae), Cryptophyta, Chlorophyta (green algae), Euglenophyta, Chlorarachniophyta, Pyrrophyta (dinoflagellates), and Chromophyta (heterokonts) [22,23].

They are widely distributed in a variety of environments such as freshwater, seawater, surface waters, water columns, deep waters, and sediments, as well as terrestrial environments, including soils rich in organic matter and sand, both in warm and cold regions, and even in extreme regions such as Antarctica [11,14,21,24]. In Colombia, through metagenomics and microbial ecology approaches, microalgae have been identified in rivers, swamps, and hot springs in different regions of the country. Nevertheless, studies on microalgae diversity are scarce [13,25-28].

\section{Nutritional Composition}

The biochemical composition of microalgae makes their production attractive for the development of different biotechnological applications (Figure 1) [29,30]. Differences in the biochemical composition are observed depending on the species and a wide range of cultivation factors [31]. In this regard, many studies have focused on the chemical analysis of microalgal biomass and its response to different nutrient sources, light, and nutrient concentrations.

\subsection{Proteins}

Proteins are essential biomolecules for living beings, mainly because of their role as a source of nitrogen and sulfur. Protein content differs among organisms, accounting the highest percentage of dry matter in some microalgal species such as Arthrospira sp. (70\%), Chlorella sp. (50-60\%), Synechococcus sp. (63\%), Dunaliella salina (57\%), and Aphanizomenon flos-aquae (62\%) [32,33]. Species such as Chlorella vulgaris, Arthrospira maxima, D. bardawil, Arthrospira platensis, and Nannochloropsis sp. contain high levels of essential amino acids such as leucine, isoleucine, valine, lysine, tryptophan, methionine, threonine, and histidine [33]. In addition, they produce non-essential amino acids, such as glycine, alanine, and tyrosine, which were found in higher levels in Scenedesmus sp. and A. platensis than in 
conventional protein sources [33]. Therefore, microalgae are an alternative protein source with additional nutritional benefits to conventional animal and plant protein sources [34].

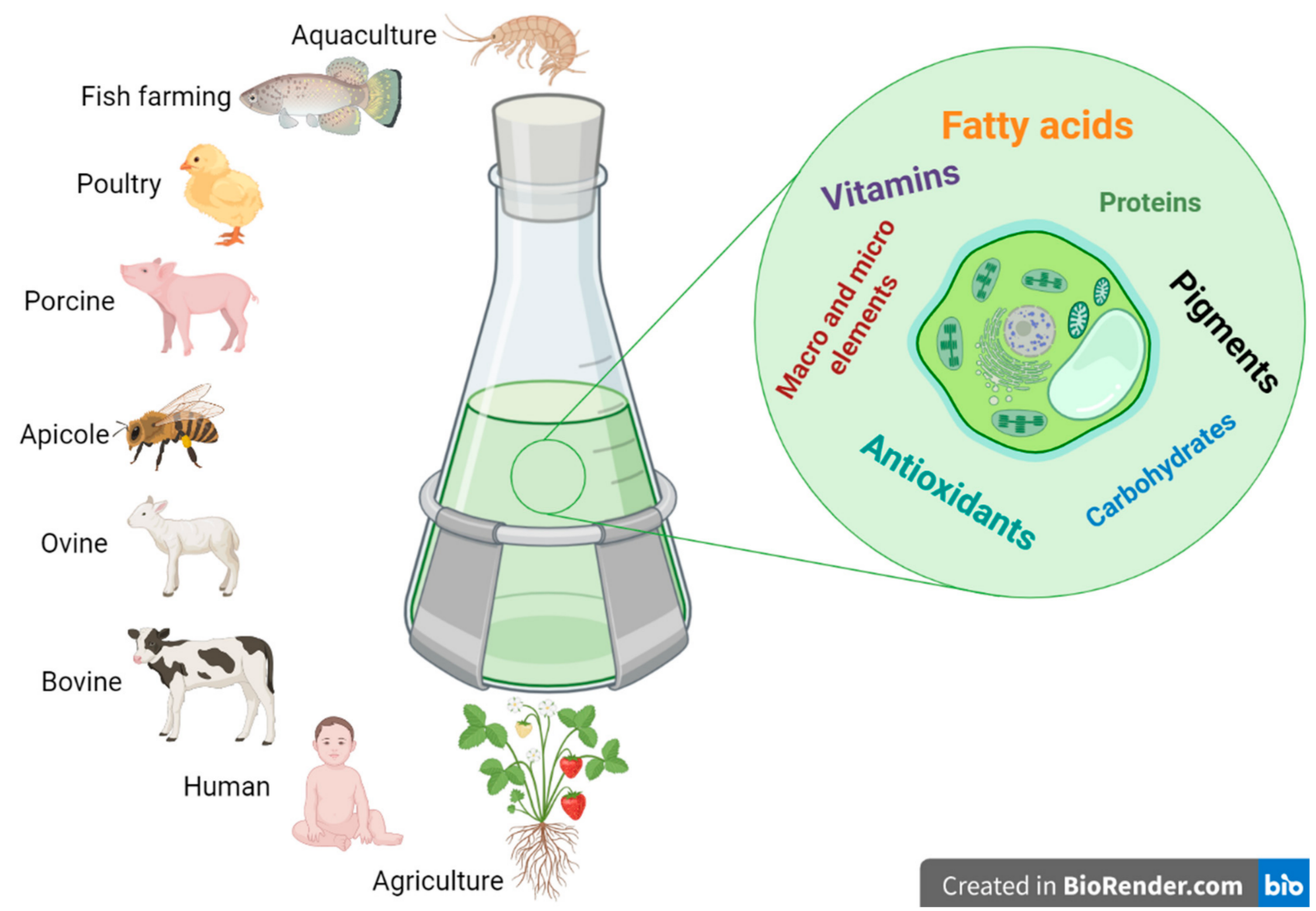

Figure 1. Biomolecules available in microalgae that are useful for human, plant, and animal nutrition.

\subsection{Carbohydrates}

Microalgae and cyanobacteria are important sources of carbohydrates. They produce large amounts of a wide range of polysaccharides for energy storage, as structural components (envelope, capsid, and slime), or are secreted (exopolysaccharides) [35,36]. Exopolysaccharides are used in industry as hydrocolloids, gelling agents, stabilizers, emulsifiers, and thickening agents [37]. Biologically, exopolysaccharides are synthesized in response to stress factors [38,39], and their composition differs among species or groups of microalgae (Charophyta, Rhodophyta, Ochrophyta, and Haptophyta) [40]. In general, they are heteropolymers. In cyanobacteria, the main monosaccharide identified is glucose [36]. Likewise, a high proportion of galactose, rhamnose, fucose, arabinose, xylose, and mannose can also be found in microalgae $[35,41]$.

\subsection{Lipids and Fatty Acids}

Microalgae accumulate lipids for growth, cell division, and as energy reservoirs under stress conditions [42]. Over the past decade, the production of microalgae oils has focused on third-generation biofuels [43]; however, a wide range of potential applications can arise from their diverse lipid composition—saturated, monounsaturated, polyunsaturated, branched fatty acids, and fatty acid amides [44]. Under optimal conditions, the total lipid production by microalgae can exceed $50 \%$ of their dry biomass. Specifically, microalgae lipid profiles are rich in polyunsaturated fatty acids, such as omega-3, omega-6, docosahexaenoic acid (DHA), and eicosapentaenoic acid (EPA) [45]. Microalgae are primary producers of EPA and DHA in aquatic systems, which enables their sub- 
sequent bioaccumulation in higher organisms. EPA and DHA may account for a high proportion of total lipids in microalgae, as observed in Nannochloropsis sp. (26-28\%), Phaeodactylum tricornutum (39\%), Chlorella sp. (39\%), Pavlova sp. (36-41\%), Schizochytrium limacinum (30-40\%), Thraustochytrium sp. (45\%), and Isocrysis sp. (28\%) [15,45,46]. Microalgae also produce other essential fatty acids, such as alpha-linolenic acid, gamma-linolenic acid, linoleic acid, and arachidonic acid [47].

\subsection{Vitamins, Pigments, and Antioxidants}

Microalgae also produce other compounds of high commercial value, such as pigments, vitamins, and antioxidants. Chlorophyll, carotenoids, and phycobilins are the most abundant pigments in microalgae and cyanobacteria [15,48]. In addition to providing coloration, they possess health-promoting properties with potential in the pharmaceutical industry as antioxidants, vitamin precursors, neuroprotectors, and immunological stimulants [49]. The most used pigments, including beta-carotene, lutein, chlorophyll a and $b$, astaxanthin, and phycocyanin, are produced by Botryococcus braunii, C. vulgaris, Chlorocococcum sp., Scenedesmus sp., Arthrospira platensis, and Haematococcus pluvialis [15].

Some microalgae are excellent sources of micronutrients, such as vitamin B12 (Cylindrospermum sp., Tolypothrix tenuis, Nostoc muscorum, and Hapalosiphon fontinalis), vitamin C (Prototheca moriformis, Chlorella sp., Arthrospira sp., and Dunaliella sp.) [15,29], vitamin E (Euglena gracilis and D. tertiolecta) [15,33], and other B-complex vitamins (B1, B3, B5, B6 in Tetraselmis suecica) [33].

Phenolic antioxidants such as rutin, hesperidin, morin, caffeic acid, catechol, and catechin are produced by some microalgae (Nostoc sp., Chlorella sp., Anabaena sp., Tolypothrix sp., and Chlamydomonas sp.) as secondary metabolites. Phenolic compounds act as free radical scavengers, hydrogen atom donors, and metal chelators. In view of these essential functions, they are used in food supplements $[49,50]$.

\section{Animal Feed}

Some microalgal species have been used in animal feed, aquaculture, and beekeeping owing to their bioactive compound content [51-53]. The source of microalgal biomass can be either cultures destined to produce nutritional supplements or residual biomass from pollutant-free industrial processes, such as biofuel production [52,54-56].

In pig farming, the use of biomass supplements or microalgae oils has been shown to strengthen the immune system and improve animal health, thus enhancing the sensory characteristics and lipid composition of the meat $[15,51,57,58]$. Nutrition in pregnant sows and fattening pigs could be optimized using species such as C. vulgaris, Arthrospira sp., Aurantiochytrium limacinum, and Desmodesmus sp.; in addition, production increases and the composition of fatty acids in meat improves, thus increasing the DHA content $[57,59,60]$.

In ruminants, food supplementation with meal or oil from some species of microalgae has been explored $[51,61,62]$. As a result, improved organoleptic properties and fatty acid composition of meat and milk were observed in bovines [63-65]. Microalgae, such as A. platensis, were shown to be a good replacement for plant supplements, and improving the quality of milk [66]. Nevertheless, different species and concentrations need to be studied in bovines to avoid possible alterations in the organoleptic characteristics of meat [56,67]. In sheep, supplementation with A. platensis increased growth and development of animals, and Schizochytrium sp. improved meat quality [68,69]. Extracts from C. sorokiniana and $D$. tertiolecta exerted positive effects on anti-inflammatory activity and immunomodulation, enabling reduction in the use of antibiotics in pregnant or postpartum females [70,71]. Finally, supplementation with C. vulgaris in the diet of goats reduces oxidative stress, improving the quality of the milk since it has greater stability and better organoleptic characteristics [72].

In chickens and hens, food supplementation with microalgae has also shown beneficial effects on animal health and meat and egg production [15,51]. For instance, improved growth and meat quality, as well as a decrease in chronic diseases in broiler 
chickens, were observed after supplementation with C. vulgaris, A. platensis, Staurosira sp., Schizochytrium sp., Aurantiochytrium sp. and Amphora coffeaeformis [51,73-76]. In laying hens, supplementation with $A$. platensis, Nannochloropsis gaditana, and Porphyridium sp. improved animal nutrition and health, as well as reduced cholesterol levels and enhanced organoleptic properties of the eggs $[73,77,78]$.

Positive effects have also been observed in rabbits. C. vulgaris and N. oceanica improved the health, growth, and meat quality of animals [79,80]. The enormous potential of microalgae has also been studied in bees. The productivity, physiology, and health of honeybees improved when fed with microalgae [53].

In 2018, fish farming production accounted for 271,610 million USD and is estimated to generate 376,480 million USD by 2025 . Therefore, the production of fish, crustaceans, mollusks, and algae is one of the most promising industries, with algae being extremely valuable [81]. Microalgae are essential in the feeding of aquatic animals [52]. The implementation of microalgae in fish farming is an environmentally friendly alternative to the non-sustainable fishmeal and fish oil-based feeds currently used. Microalgae have been successfully tested in salmon, trout, tilapia, ornamental fish, and crustaceans $[51,82]$. In farmed shrimp, feeding with T. chuii, Dunaliella sp., A. platensis, Hypnea cervicornis, and Cryptonemia crenulata improved both immunity and production [52,83]. Salmon and carp fed with Nanofrustulum sp., Tetraselmis sp., and Haematococcus pluvialis, and tilapia fed with N. oculata, and Schizochytrium sp. showed improved health and higher nutritional value compared to the meat [82,84-86].

The development of animal feed products based on microalgae is a promising field. However, a thorough knowledge of the characteristics of the species used, especially their cultivation, physiology, and secondary metabolites, is key to ensuring beneficial effects, high productivity, and efficiency. This is essential considering that some species of cyanobacteria and dinoflagellates produce molecules that are toxic to invertebrates and vertebrates $[20,87,88]$.

\section{Applications in Human Nutrition}

The need for mass food production and the search for sustainable processes have led to the development of new strategies for food production with low impact on the environment. The use of microalgae as a food source has been studied since the late 1980s [89]; however, only in recent years has it generated greater interest. A. platensis (spirulina) is one of the most widely used microalgae. The interest in this microalga for human consumption is based on the nutritional characteristics of its biomass, which are comparable to those of meat and soybeans, as well as on its vitamin, phenolic compound, mineral, amino acid, and essential fatty acid content [90].

In addition to basic nutritional properties, other benefits of microalgae for human health have been described [51,91,92]. For instance, foods supplemented with Arthrospira sp., C. vulgaris, A. platensis, $H$. pluvialis, and D. salina had positive effects on the anti-inflammatory activity, immune system, and properties that can regulate hyperglycemia and hyperlipidemia and protect against oxidative stress [15,51,91-96].

The biosafety and toxicity of lipid compounds extracted from N. oculata, Rhodococcus opacus, Schizochytrium sp., and Crypthecodinium cohnii have been assessed. These compounds are used as an alternative food to human breast milk. No cytotoxic effects were observed, supporting the feasibility of using microalgae oils for human nutrition from birth to 2 years of age or more [97-99]. Similarly, the composition and use of species such as B. braunii, C. vulgaris, H. pluvialis, and Isochrysis galbana have been studied. These species are an ideal vegetarian supplement because they contain essential amino acids, as well as omega- 3 and omega- 6 fatty acids $[15,100]$.

Based on their high nutritional value, reduced environmental impact, and economic sustainability, microalgae have been used as functional ingredients to enhance the characteristics of foods [101], such as milk or dairy products [99] and meat products [90], or in the manufacturing of snacks [102,103], food supplements [104,105], and food pig- 
ments $[103,106]$. This highlights the importance of research, development, and innovation in the use of microalgae for human consumption.

\section{Agriculture}

Crops can be greatly affected by the lack of phosphate. Novel alternative sources have needed to be developed due to the limited availability of this mineral and the negative impact that the application of inorganic phosphate compounds has on soils $[107,108]$. Phosphate is ubiquitously found in biomolecules and physiological processes in living organisms [109,110]. A viable option is the use of biomass for phosphate recycling [107]. In particular, microalgal biomass can provide an additional benefit because the biomass obtained from wastewater treatment can be used as an environmentally friendly fertilizer [16]. Microalgae are a feasible sustainable alternative and their use as fertilizers offers an opportunity to reduce the current dependence on agrochemicals that in most cases has secondary or detrimental effects [111]. Microalgae benefit plants by increasing nutrient availability, producing phytohormones, forming associations with roots, and protecting against pathogens and pests [16].

Some researchers have proposed that the mechanisms through which microalgae promote plant growth are associated with signaling and nutrition, such as the uptake of substances excreted by microalgae. However, these mechanisms remain unclear and further studies should be conducted in this regard [111,112]. Microalgae have been shown to be a feasible alternative to the use of chemical fertilizers because of their ability to accumulate nutrients in the form of polyphosphate granules [111]. The effects of microalgae on plant growth have been studied using species such as Chlorella sp., Gloeocapsa sp., Oscillatoria amphibia, Microcystis aeruginosa, Synechococcus rubescens, and Cyanobium gracile $[111,113,114]$. C. vulgaris and C. sorokiniana promoted the growth of Triticum aestivum, releasing phosphate gradually and progressively over time $[107,111,112]$. Likewise, fertilization with Microcystis aeruginosa MKR0105, Anabaena sp. PCC7120, and Chlorella sp. enhanced plant growth and physiological performance by increasing cell membrane stability, chlorophyll synthesis, photosynthetic rate, stomatal conductance, and decreasing intracellular $\mathrm{CO}_{2}$ concentration [115]. Finally, the biomass of Scenedesmus sp. was proven to be effective as a biofertilizer and can be applied in combination with chemical fertilizers, which may help to reduce excessive use of the latter [116].

\section{Microalgae Production in Colombia}

Microalgae are investigated and cultivated worldwide to search for new species and obtain a wide range of products. Countries such as the United States, China, Japan, and India are the main producers and developers of biotechnological advances $[117,118]$. In Colombia, there are few studies focused on the use of microalgae in food, animal production, and agriculture, despite the enormous potential of its biodiversity, water resources, climate, as well as the fulfilling needs driven by the high rates of poverty and malnutrition in the country [7]. In contrast, research in Colombia is mainly focused on the use of microalgae in the production of total lipids for biodiesel, wastewater treatment, and bioremediation [119-124]. Some research has recently begun in the agro-alimentary sector; however, little has been implemented in recent years (Table 1). In addition, there is increasing consumption of supplements based on microalgae, such as Arthrospira spp. and Chlorella sp., however, these are imported products. Therefore, these initial studies constitute a baseline for a promising future of the Colombian bioeconomy based on microalgae. 
Table 1. Studies conducted in Colombia over the past 5 years on microalgae as a food supplement.

\begin{tabular}{|c|c|c|c|c|}
\hline Application & Microalga & Product & Conclusion & Reference \\
\hline \multirow[b]{2}{*}{ Human food } & Crypthecodinium cohnii & Yogurt with microalgae oil & $\begin{array}{c}\text { Addition of microalgae oil increases } \\
\text { DHA in the diet. }\end{array}$ & [124] \\
\hline & Arthrospira maxima & Biomass & $\begin{array}{l}\text { Mass production of dry biomass } \\
(1 \mathrm{~g} / \mathrm{L}) \text { was accomplished by outdoor } \\
\text { scale-up. }\end{array}$ & [125] \\
\hline \multirow{3}{*}{ Animal feed } & Scenedesmus sp. & Rotifer food & $\begin{array}{l}\text { Increased population density was } \\
\text { observed after feeding with } \\
\text { Scenedesmus sp. }\end{array}$ & [126] \\
\hline & Chlorella sp. & $\begin{array}{l}\text { Zooplankton food } \\
\text { (Macrothrix spinosa) }\end{array}$ & $\begin{array}{l}\text { M. spinosa fed with Chlorella sp. } \\
\text { showed better performance. }\end{array}$ & [127] \\
\hline & $\begin{array}{l}\text { Cylindrotheca closterium, } \\
\text { Entomoneis alata, Plagiotropis } \\
\text { lepidoptera, Komvophoron } \\
\text { crassum, Synechococcus sp., } \\
\text { Tetraselmis chuii }\end{array}$ & Food in marine aquaculture & $\begin{array}{l}\text { Benthic microalgae showed potential } \\
\text { for use as feed in marine aquaculture. }\end{array}$ & [113] \\
\hline \multirow[b]{2}{*}{ Agriculture } & $\begin{array}{l}\text { Gloeocapsa sp., } \\
\text { Oscillatoria amphibia }\end{array}$ & $\begin{array}{l}\text { Biofertilizer for rice, corn, and } \\
\text { bean crops }\end{array}$ & $\begin{array}{c}\text { Gloeocapsa sp. increased growth in rice } \\
\text { plants by } 15.0 \% \text {. }\end{array}$ & [112] \\
\hline & $\begin{array}{l}\text { Consortium of Microcystis } \\
\text { aeruginosa, Synechococcus } \\
\text { rubescens, Cyanobium gracile }\end{array}$ & Biofertilizer for gulupa crop & $\begin{array}{l}\text { The results were similar to those of a } \\
\text { traditional organic treatment. }\end{array}$ & [128] \\
\hline \multirow{6}{*}{ Other uses } & Chlorella vulgaris & $\begin{array}{l}\text { Lipid and carbohydrate } \\
\text { production }\end{array}$ & $\begin{array}{c}\text { Increased carbohydrates and lipids } \\
\text { levels after addition of acetate, } \\
\text { carbonate, and phosphate. }\end{array}$ & [129] \\
\hline & Botryococcus braunii & $\begin{array}{l}\text { Fatty acids and } \\
\text { exopolysaccharides }\end{array}$ & $\begin{array}{l}\text { Galactose was the main component of } \\
\text { exopolysaccharides }(71.73 \%) .\end{array}$ & [130] \\
\hline & Chlorella sp., Scenedesmus sp. & Polyunsaturated fatty acids & $\begin{array}{l}\text { Oleic acid was the major fatty acid } \\
\text { present }(28.75 \%) .\end{array}$ & [131] \\
\hline & Scenedesmus sp. & Carotenoids & $\begin{array}{l}\text { C:N ratio affected biomass and } \\
\text { carotenoid production. }\end{array}$ & [132] \\
\hline & Haematococcus pluvialis & Astaxanthin & $\begin{array}{l}\text { The highest astaxanthin production } \\
\text { was obtained in RM growth medium } \\
(8.3 \mu \mathrm{g} / \mathrm{mL}) \text {. }\end{array}$ & [133] \\
\hline & H. pluvialis & Astaxanthin & $\begin{array}{l}\text { Higher concentrations of astaxanthin } \\
\text { were obtained when limiting nitrogen } \\
\text { and phosphorus. }\end{array}$ & [134] \\
\hline
\end{tabular}

\section{Conclusions}

The global food demand, along with the need to develop environmentally friendly biotechnologies, urge the implementation of sustainable production models that consider social, environmental, and economic factors, which allow for fighting hunger and poverty, within the context of climate change, is both present and future challenge for Latin America and the world. In this regard, research and production projects conducted in several countries have shown that the use of microalgae in human food and animal feed, as well as in plant fertilization, offers multiple nutritional, economic, and environmental benefits. This industry has developed little in Colombia, but the climate and water resources available are advantageous for microalgae cultivation and production for the food industry, sustainable agricultural and livestock production, among other uses. In addition, the country's native biodiversity provides opportunities for exploring new species with biotechnological applications in the food, pharmaceutical, energy, and environmental sectors. Therefore, the bioprospecting, cultivation, and use of microalgae could be an excellent strategy for the development of the bioeconomy in Colombia. Further studies and investments are required to better identify the country's microalgae biodiversity and develop new sustainable biotechnological products. To do this, it is necessary to increase academic, investigative, technological, and productive capacities, implement public policies that promote these activities, as well as increase financing from the public and private sectors that allow for 
the development of this considerable biotechnological and economic potential, which will contribute to the Sustainable Development Goals.

Author Contributions: Conceptualization, E.M.S. and Y.A.D.; validation E.M.S. and Y.A.D.; writingoriginal draft preparation, M.C.S., A.M. and A.G.; writing-review and editing, E.M.S. and Y.A.D.; supervision, Y.A.D. All authors have read and agreed to the published version of the manuscript.

Funding: This work was funded by SGR/Sucre Governorate (Grant BPIN 2017000100035).

Institutional Review Board Statement: Not applicable.

Informed Consent Statement: Not applicable.

Data Availability Statement: Data available in a publicly accessible repository. The data presented in this study are openly available in Web of Science.

Conflicts of Interest: The authors declare no conflict of interest.

\section{References}

1. IDEAM. Zonificación y Codificación de Unidades Hidrográficas e Hidrogeológicas de Colombia; Publicación Comité de Comunicaciones y Publicaciones del IDEAM: Bogotá, Colombia, 2013; pp. 1-47.

2. Moreno, M.; Aguirre, R. Estado Del Arte de la Limnología de Lagos de Planos Inundables state of the art of limnology and flood plain lakes (Swamps) in Colombia. Rev. Gestión Ambient. 2009, 12, 85-105.

3. Invemar. Los Ambientes Marinos y Costeros en Colombia: Año 2005; Serie de Publicaciones Periódicas; Instituto de Investigaciones Marionas y Costera: Santa Marta, Columbia, 2006; Volume 8, pp. 36-43.

4. Noreña, P.A.; González Muñoz, A.; Mosquera-Rendón, J.; Botero, K.; Cristancho, M.A. Colombia, an unknown genetic diversity in the era of Big Data. BMC Genom. 2018, 19, 859. [CrossRef] [PubMed]

5. Etter, A.; Andrade, Á.; Saavedra, K.; Amaya, P.; Arévalo, P. Estado de los Ecosistemas Colombianos: Una aplicación de la Metodología de la Lista Roja de Ecosistemas; Pontificia Universidad Javeriana y Conservación Internacional: Bogotá, Colombia, 2017; pp. 1-108.

6. DANE. Incidencia de la Pobreza Monetaria. Indicadores Relevantes. Available online: https://sitios.dane.gov.co/indicadoresrelevantes/ (accessed on 20 July 2021).

7. Aguilar, A.; Twardowski, T.; Wohlgemuth, R. Bioeconomy for sustainable development. Biotechnol. J. 2019, 14, e1800638. [CrossRef] [PubMed]

8. Issa, I.; Delbrück, S.; Hamm, U. Bioeconomy from experts' perspectives-Results of a global expert survey. PLoS ONE 2019, 14, e0215917. [CrossRef] [PubMed]

9. International Advisory Council on Global Bioeconomy. Global Bioeconomy Policy Report (IV): A Decade of Bioeconomy Policy Development around the World; International Advisory Council on Global Bioeconomy: Berlin, Germany, 2020; Volume 4. Available online: https:/ /gbs2020.net/about/international-advisory-council/ (accessed on 22 July 2021).

10. CONPES. CONPES-3934-Política de Crecimiento Verde. Dep. Nac. Planeac. 2018, 1, 1-44.

11. Singh, J.; Saxena, R.C. An introduction to microalgae. In Handbook of Marine Microalgae; Elsevier: Amsterdam, The Netherlands, 2015; pp. 11-24.

12. Gómez-Luna, L. Microalgas: Aspectos ecológicos y biotecnológicos. Rev. Cuba. Quim. 2007, 19, 3-20.

13. Metting, F.B. Biodiversity and application of microalgae. J. Ind. Microbiol. Biotechnol. 1996, 17, 477-489. [CrossRef]

14. Henry, E.C. Handbook of microalgal culture: Biotechnology and applied phycology. J. Phycol. 2004, 40, 1001-1002. [CrossRef]

15. Núñez-Avellaneda, M. Microalgas acuáticas: La otra escala de la biodiversidad en la Amazonía colombiana. Inst. Amaz. Investig. Cient. SINCHI 2008, 1, 221.

16. Norton, T.A.; Melkonian, M.; Andersen, R.A. Algal biodiversity. Phycologia 1996, 35, 308-326. [CrossRef]

17. Kusmayadi, A.; Leong, Y.K.; Yen, H.W.; Huang, C.Y.; Chang, J.S. Microalgae as sustainable food and feed sources for animals and humans-Biotechnological and environmental aspects. Chemosphere 2021, 271, 129800. [CrossRef]

18. Alvarez, A.L.; Weyers, S.L.; Goemann, H.M.; Peyton, B.M.; Gardner, R.D. Microalgae, soil and plants: A critical review of microalgae as renewable resources for agriculture. Algal Res. 2021, 54, 102200. [CrossRef]

19. Sandesh Suresh, K.; Suresh, P.V.; Kudre, T.G. Prospective ecofuel feedstocks for sustainable production. In Advances in Eco-Fuels for a Sustainable Environment; Elsevier: London, UK, 2019; pp. 89-117.

20. Broady, P.A. Diversity, distribution and dispersal of Antarctic terrestrial algae. Biodivers. Conserv. 1996, 5, 1307-1335. [CrossRef]

21. Ummalyma, S.B.; Pandey, A.; Sukumaran, R.K.; Sahoo, D. Bioremediation by microalgae: Current and emerging trends for effluents treatments for value addition of waste streams. In Energy, Environment, and Sustainability, 1st ed.; Springer: Singapore, 2018; pp. 355-375, ISBN 978-981-10-7434-9.

22. Heimann, K.; Huerlimann, R. Microalgal Classification: Major Classes and Genera of Commercial Microalgal Species. In Handbook of Marine Microalgae; Elsevier: London, UK, 2015; pp. 25-41.

23. Pagels, F.; Salvaterra, D.; Amaro, H.M.; Guedes, A.C. Pigments from microalgae. In Handbook of Microalgae-Based Processes and Products; Elsevier: London, UK, 2020; pp. 465-492. 
24. Matsunaga, T.; Takeyama, H.; Miyashita, H.; Yokouchi, H. Marine microalgae. Adv. Biochem. Eng. Biotechnol. 2005, 96, 165-188. [PubMed]

25. Arbeláez, M.N.; Mancera-Pineda, J.E.; Reguera, B. Structural variation of potentially toxic epiphytic dinoflagellates on thalassia testudinum from two coastal systems of Colombian Caribbean. Harmful Algae 2020, 92, 101738. [CrossRef]

26. Morales-Parrado, J.; García-Alzate, C.A. Estructura Trófica de la Ictiofauna de los arroyos del Corral de San Luis, Cuenca del Bajo Magdalena, Colombia. Rev. Biol. Trop. 2016, 64, 715-732. [CrossRef]

27. Jiménez, D.J.; Andreote, F.D.; Chaves, D.; Montaña, J.S.; Osorio-Forero, C.; Junca, H.; Zambrano, M.M.; Baena, S. Structural and functional insights from the metagenome of an acidic hot spring microbial planktonic community in the Colombian Andes. PLoS ONE 2012, 7, e52069. [CrossRef]

28. Bohorquez, L.C.; Delgado-Serrano, L.; López, G.; Osorio-Forero, C.; Klepac-Ceraj, V.; Kolter, R.; Junca, H.; Baena, S.; Zambrano, M.M. In-depth characterization via complementing culture-independent approaches of the microbial community in an acidic hot spring of the Colombian Andes. Microb. Ecol. 2012, 63, 103-115. [CrossRef] [PubMed]

29. Rizwan, M.; Mujtaba, G.; Memon, S.A.; Lee, K.; Rashid, N. Exploring the potential of microalgae for new biotechnology applications and beyond: A review. Renew. Sustain. Energy Rev. 2018, 92, 394-404. [CrossRef]

30. Fernández, F.G.A.; Reis, A.; Wijffels, R.H.; Barbosa, M.; Verdelho, V.; Llamas, B. The role of microalgae in the bioeconomy. New Biotechnol. 2021, 61, 99-107. [CrossRef] [PubMed]

31. Yaakob, M.A.; Mohamed, R.M.S.R.; Al-Gheethi, A.; Aswathnarayana Gokare, R.; Ambati, R.R. Influence of nitrogen and phosphorus on microalgal growth, biomass, lipid, and fatty acid production: An overview. Cells 2021, 10, 393. [CrossRef] [PubMed]

32. Christaki, E.; Florou-Paneri, P.; Bonos, E. Microalgae: A novel ingredient in nutrition. Int. J. Food Sci. Nutr. 2011, 62, 794-799. [CrossRef]

33. Koyande, A.K.; Chew, K.W.; Rambabu, K.; Tao, Y.; Chu, D.T.; Show, P.L. Microalgae: A potential alternative to health supplementation for humans. Food Sci. Hum. Wellness 2019, 8, 16-24. [CrossRef]

34. Chacón-Lee, T.L.; González-Mariño, G.E. Microalgae for 'healthy' foods-possibilities and challenges. Compr. Rev. Food Sci. Food Saf. 2010, 9, 655-675. [CrossRef]

35. Delattre, C.; Pierre, G.; Laroche, C.; Michaud, P. Production, extraction and characterization of microalgal and cyanobacterial exopolysaccharides. Biotechnol. Adv. 2016, 34, 1159-1179. [CrossRef] [PubMed]

36. Gaignard, C.; Laroche, C.; Pierre, G.; Dubessay, P.; Delattre, C.; Gardarin, C.; Gourvil, P.; Probert, I.; Dubuffet, A.; Michaud, P. Screening of marine microalgae: Investigation of new exopolysaccharide producers. Algal Res. 2019, 44, 101711. [CrossRef]

37. Singh, S.; Kant, C.; Yadav, R.K.; Reddy, Y.P.; Abraham, G. Cyanobacterial Exopolysaccharides: Composition, Biosynthesis, and Biotechnological Applications in Cyanobacteria: From Basic Science to Applications; Elsevier: Amsterdam, The Netherlands, 2018; pp. 347-358.

38. Demura, M.; Ioki, M.; Kawachi, M.; Nakajima, N.; Watanabe, M.M. Desiccation tolerance of Botryococcus braunii (Trebouxiophyceae, Chlorophyta) and extreme temperature tolerance of dehydrated cells. J. Appl. Phycol. 2014, 26, 49-53. [CrossRef] [PubMed]

39. Chen, B.; Li, F.; Liu, N.; Ge, F.; Xiao, H.; Yang, Y. Role of extracellular polymeric substances from Chlorella vulgaris in the removal of ammonium and orthophosphate under the stress of cadmium. Bioresour. Technol. 2015, 190, 299-306. [CrossRef]

40. Pierre, G.; Delattre, C.; Dubessay, P.; Jubeau, S.; Vialleix, C.; Cadoret, J.P.; Probert, I.; Michaud, P. What is in store for EPS microalgae in the next decade? Molecules 2019, 24, 4296. [CrossRef]

41. Kumar, D.; Kaštánek, P.; Adhikary, S.P. Exopolysaccharides from cyanobacteria and microalgae and their commercial application. Curr. Sci. 2018, 115, 234-241. [CrossRef]

42. Zienkiewicz, K.; Du, Z.Y.; Ma, W.; Vollheyde, K.; Benning, C. Stress-induced neutral lipid biosynthesis in microalgae-Molecular, cellular and physiological insights. Biochim. Biophys. Acta 2016, 1861, 1269-1281. [CrossRef] [PubMed]

43. Ananthi, V.; Raja, R.; Carvalho, I.S.; Brindhadevi, K.; Pugazhendhi, A.; Arun, A. A realistic scenario on microalgae based biodiesel production: Third generation biofuel. Fuel 2021, 284, 118965. [CrossRef]

44. Maltsev, Y.; Maltseva, K. Fatty acids of microalgae: Diversity and applications. Rev. Environ. Sci. Bio Technol. 2021, 20, 515-547. [CrossRef]

45. Adarme-Vega, T.C.; Lim, D.K.Y.; Timmins, M.; Vernen, F.; Li, Y.; Schenk, P.M. Microalgal biofactories: A promising approach towards sustainable omega-3 fatty acid production. Microb. Cell Factories 2012, 11, 96. [CrossRef]

46. Ramesh Kumar, B.; Deviram, G.; Mathimani, T.; Duc, P.A.; Pugazhendhi, A. Microalgae as rich source of polyunsaturated fatty acids. Biocatal. Agric. Biotechnol. 2019, 17, 583-588. [CrossRef]

47. Freitas, H.R. Chlorella vulgaris as a source of essential fatty acids and micronutrients: A brief commentary. Open Plant. Sci. J. 2017, 10, 92-99. [CrossRef]

48. Silva, S.C.; Ferreira, I.C.F.R.; Dias, M.M.; Barreiro, M.F. Microalgae-derived pigments: A 10-year bibliometric review and industry and market trend analysis. Molecules 2020, 25, 3406. [CrossRef]

49. Mobin, S.M.A.; Chowdhury, H.; Alam, F. Commercially important bioproducts from microalgae and their current applications-A review. Energy Procedia 2019, 160, 752-760. [CrossRef]

50. Kaur, P. Microalgae as nutraceutical for achieving sustainable food solution in future. In Environmental and Microbial Biotechnology; Springer: Singapore, 2020; pp. 91-125.

51. Camacho, F.; Macedo, A.; Malcata, F. Potential industrial applications and commercialization of microalgae in the functional food and feed industries: A short review. Mar. Drugs 2019, 17, 312. [CrossRef] 
52. Yaakob, Z.; Ali, E.; Zainal, A.; Mohamad, M.; Takriff, M.S. An overview: Biomolecules from microalgae for animal feed and aquaculture. J. Biol. Res. 2014, 21, 6. [CrossRef]

53. Ricigliano, V.A. Microalgae as a promising and sustainable nutrition source for managed honey bees. Arch. Insect Biochem. Physiol. 2020, 104, e21658. [CrossRef]

54. Gatrell, S.; Lum, K.; Kim, J.; Lei, X.G. Nonruminant nutrition symposium: Potential of defatted microalgae from the biofuel industry as an ingredient to replace corn and soybean meal in swine and poultry diets. J. Anim. Sci. 2014, 92, 1306-1314. [CrossRef]

55. Zhou, W.; Hu, B.; Li, Y.; Min, M.; Mohr, M.; Du, Z.; Chen, P.; Ruan, R. Mass cultivation of microalgae on animal wastewater: A sequential two-stage cultivation process for energy crop and Omega-3-rich animal feed production. Appl. Biochem. Biotechnol. 2012, 168, 348-363. [CrossRef] [PubMed]

56. Fuentes-Grünewald, C.; Ignacio Gayo-Peláez, J.; Ndovela, V.; Wood, E.; Vijay Kapoore, R.; Anne Llewellyn, C. Towards a circular economy: A novel microalgal two-step growth approach to treat excess nutrients from digestate and to produce biomass for animal feed. Bioresour. Technol. 2021, 320, 124349. [CrossRef]

57. Lee, A.V.; You, L.; Oh, S.Y.; Li, Z.; Fisher-Heffernan, R.E.; Regnault, T.R.H.; de Lange, C.F.M.; Huber, L.; Karrow, N.A. Microalgae supplementation to late gestation sows and its effects on the health status of weaned piglets fed diets containing high or low-quality protein sources. Vet. Immunol. Immunopathol. 2019, 218, 109937. [CrossRef] [PubMed]

58. You, L.; Lee, A.V.; Oh, S.Y.; Fisher-Heffernan, R.E.; Edwards, M.; de Lange, K.; Karrow, N.A. Effect of lipopolysaccharideinduced immune stimulation and maternal fish oil and microalgae supplementation during late pregnancy on nursery pig hypothalamic-pituitary-adrenal function1. J. Anim. Sci. 2019, 97, 2940-2951. [CrossRef] [PubMed]

59. de Tonnac, A.; Guillevic, M.; Mourot, J. Fatty acid composition of several muscles and adipose tissues of pigs fed n-3 PUFA rich diets. Meat Sci. 2018, 140, 1-8. [CrossRef]

60. Moran, C.A.; Morlacchini, M.; Keegan, J.D.; Delles, R.; Fusconi, G. Effects of a DHA-rich unextracted microalgae as a dietary supplement on performance, carcass traits and meat fatty acid profile in growing-finishing pigs. J. Anim. Physiol. Anim. Nutr. 2018, 102, 1026-1038. [CrossRef]

61. Stokes, R.S.; Van Emon, M.L.; Loy, D.D.; Hansen, S.L. Assessment of algae meal as a ruminant feedstuff: Nutrient digestibility in sheep as a model species. J. Anim. Sci. 2015, 93, 5386-5394. [CrossRef]

62. Holman, B.W.B.; Malau-Aduli, A.E.O. Spirulina as a livestock supplement and animal feed. J. Anim. Physiol. Anim. Nutr. 2013, 97, 615-623. [CrossRef]

63. Till, B.E.; Huntington, J.A.; Posri, W.; Early, R.; Taylor-Pickard, J.; Sinclair, L.A. Influence of rate of inclusion of microalgae on the sensory characteristics and fatty acid composition of cheese and performance of dairy cows. J. Dairy Sci. 2019, 102, 10934-10946. [CrossRef] [PubMed]

64. Till, B.E.; Huntington, J.A.; Kliem, K.E.; Taylor-Pickard, J.; Sinclair, L.A. Long term dietary supplementation with microalgae increases plasma docosahexaenoic acid in milk and plasma but does not affect plasma 13,14-dihydro-15-keto PGF $2 \alpha$ concentration in dairy cows. J. Dairy Res. 2020, 87, 14-22. [CrossRef] [PubMed]

65. Flaga, J.; Korytkowski, Ł.; Górka, P.; Kowalski, Z.M. The effect of docosahexaenoic acid-rich algae supplementation in milk replacer on performance and selected immune system functions in calves. J. Dairy Sci. 2019, 102, 8862-8873. [CrossRef] [PubMed]

66. Lamminen, M.; Halmemies-Beauchet-Filleau, A.; Kokkonen, T.; Vanhatalo, A.; Jaakkola, S. The effect of partial substitution of rapeseed meal and faba beans by Spirulina platensis microalgae on milk production, nitrogen utilization, and amino acid metabolism of lactating dairy cows. J. Dairy Sci. 2019, 102, 7102-7117. [CrossRef]

67. Stokes, R.S.; Loy, D.D.; Hansen, S.L. Effects of increased inclusion of algae meal on finishing steer performance and carcass characteristics1. J. Anim. Sci. 2016, 94, 687-696. [CrossRef]

68. Holman, B. Growth and body conformation responses of genetically divergent Australian sheep to Spirulina (Arthrospira platensis) supplementation. Am. J. Exp. Agric. 2012, 2, 160-173. [CrossRef]

69. Fan, Y.; Ren, C.; Meng, F.; Deng, K.; Zhang, G.; Wang, F. Effects of algae supplementation in high-energy dietary on fatty acid composition and the expression of genes involved in lipid metabolism in Hu sheep managed under intensive finishing system. Meat Sci. 2019, 157, 107872. [CrossRef]

70. Ciliberti, M.G.; Albenzio, M.; Francavilla, M.; Neglia, G.; Esposito, L.; Caroprese, M. Extracts from microalga Chlorella sorokiniana exert an anti-proliferative effect and modulate cytokines in sheep peripheral blood mononuclear cells. Animals 2019, 9, 45. [CrossRef]

71. Caroprese, M.; Albenzio, M.; Ciliberti, M.G.; Francavilla, M.; Sevi, A. A mixture of phytosterols from Dunaliella tertiolecta affects proliferation of peripheral blood mononuclear cells and cytokine production in sheep. Vet. Immunol. Immunopathol. 2012, 150, 27-35. [CrossRef]

72. Tsiplakou, E.; Abdullah, M.A.M.; Mavrommatis, A.; Chatzikonstantinou, M.; Skliros, D.; Sotirakoglou, K.; Flemetakis, E.; Labrou, N.E.; Zervas, G. The effect of dietary Chlorella vulgaris inclusion on goat's milk chemical composition, fatty acids profile and enzymes activities related to oxidation. J. Anim. Physiol. Anim. Nutr. (Berlin) 2018, 102, 142-151. [CrossRef]

73. El-Bahr, S.; Shousha, S.; Shehab, A.; Khattab, W.; Ahmed-Farid, O.; Sabike, I.; El-Garhy, O.; Albokhadaim, I.; Albosadah, K. Effect of dietary microalgae on growth performance, profiles of amino and fatty acids, antioxidant status, and meat quality of broiler chickens. Animals 2020, 10, 761. [CrossRef] [PubMed] 
74. Tolba, S.A.; Sun, T.; Magnuson, A.D.; Liu, G.C.; Abdel-Razik, W.M.; El-Gamal, M.F.; Lei, X.G. Supplemental docosahexaenoicacid-enriched microalgae affected fatty acid and metabolic profiles and related gene expression in several tissues of broiler chicks. J. Agric. Food Chem. 2019, 67, 6497-6507. [CrossRef]

75. Tavernari, F.C.; Roza, L.F.; Surek, D.; Sordi, C.; Silva, M.L.B.D.; Albino, L.F.T.; Migliorini, M.J.; Paiano, D.; Boiago, M.M. Apparent metabolisable energy and amino acid digestibility of microalgae Spirulina platensis as an ingredient in broiler chicken diets. $\mathrm{Br}$. Poult. Sci. 2018, 59, 562-567. [CrossRef] [PubMed]

76. Khan, I.A.; Parker, N.B.; Löhr, C.V.; Cherian, G. Docosahexaenoic acid (22:6 n-3)-rich microalgae along with methionine supplementation in broiler chickens: Effects on production performance, breast muscle quality attributes, lipid profile, and incidence of white striping and myopathy. Poult. Sci. 2021, 100, 865-874. [CrossRef] [PubMed]

77. Ginzberg, A.; Cohen, M.; Sod-Moriah, U.A.; Shany, S.; Rosenshtrauch, A.; Arad, S. Chickens fed with biomass of the red microalga Porphyridium sp. have reduced blood cholesterol level and modified fatty acid composition in egg yolk. J. Appl. Phycol. 2000, 12, 325-330. [CrossRef]

78. Feng, J.; Long, S.; Zhang, H.J.; Wu, S.G.; Qi, G.H.; Wang, J. Comparative effects of dietary microalgae oil and fish oil on fatty acid composition and sensory quality of table eggs. Poult. Sci. 2020, 99, 1734-1743. [CrossRef]

79. Abdelnour, S.A.; Sheiha, A.M.; Taha, A.E.; Swelum, A.A.; Alarifi, S.; Alkahtani, S.; Ali, D.; AlBasher, G.; Almeer, R.; Falodah, F.; et al. Impacts of enriching growing rabbit diets with Chlorella vulgaris microalgae on growth, blood variables, carcass traits, immunological and antioxidant indices. Animals 2019, 9, 788. [CrossRef]

80. Ribeiro, D.M.; Bandarrinha, J.; Nanni, P.; Alves, S.P.; Martins, C.F.; Bessa, R.J.B.; Falcão-E-Cunha, L.; Almeida, A.M. The effect of Nannochloropsis oceanica feed inclusion on rabbit muscle proteome. J. Proteom. 2020, 222, 103783. [CrossRef]

81. Sumesh, K.; Roshan, D. Fish Farming Market by Environment (Marine Water, Fresh Water, and Brackish Water), and Fish Type (Pompano, Snappers, Groupers, Salmon, Milkfish, Tuna, Tilapia, Catfish, Sea Bass, \& Others): Global Opportunity Analysis and Industry Forecast 2021-2027. Available online: https: / www.giiresearch.com/report/amr980757-fish-farming-market-byenvironment-marine-water.html (accessed on 27 July 2021).

82. Sarker, P.K.; Kapuscinski, A.R.; McKuin, B.; Fitzgerald, D.S.; Nash, H.M.; Greenwood, C. Microalgae-blend tilapia feed eliminates fishmeal and fish oil, improves growth, and is cost viable. Sci. Rep. 2020, 10, 19328. [CrossRef]

83. Hernández-Camacho, J.; Sánchez Páez, H. La diversidad biológica de Iberoamerica. In Biomas Terrestres de Colombia, 1st ed.; Instituto de Ecología: Ciudad de México, México, 1992; Volume 1, pp. 153-174.

84. Kiron, V.; Phromkunthong, W.; Huntley, M.; Archibald, I.; De Scheemaker, G. Marine microalgae from biorefinery as a potential feed protein source for Atlantic salmon, common carp and whiteleg shrimp. Aquac. Nutr. 2012, 18, 1-11. [CrossRef]

85. Sheikhzadeh, N.; Tayefi-Nasrabadi, H.; Oushani, A.K.; Enferadi, M.H. Effects of Haematococcus pluvialis supplementation on antioxidant system and metabolism in rainbow trout (Oncorhynchus mykiss). Fish Physiol. Biochem. 2012, 38, 413-419. [CrossRef]

86. Stoneham, T.R.; Kuhn, D.D.; Taylor, D.P.; Neilson, A.P.; Smith, S.A.; Gatlin, D.M.; Chu, H.S.S.; O'Keefe, S.F. Production of omega-3 enriched tilapia through the dietary use of algae meal or fish oil: Improved nutrient value of fillet and offal. PLoS ONE 2018, 13, e0194241. [CrossRef]

87. Svirčev, Z.; Lalić, D.; Bojadžija Savić, G.; Tokodi, N.; Drobac Backović, D.; Chen, L.; Meriluoto, J.; Codd, G.A. Global geographical and historical overview of cyanotoxin distribution and cyanobacterial poisonings. Arch. Toxicol. 2019, 93, $2429-2481$. [CrossRef] [PubMed]

88. Reguera, B.; Blanco, J. Dinophysis toxins: Distribution, fate in shellfish and impacts. Toxins 2019, 11, 413. [CrossRef] [PubMed]

89. Gross, R.; Schoeneberger, H.; Gross, U. The nutritional quality of Scenedesmus acutus in a semi-industrial plant in Peru. J. Environ. Pathol. Toxicol. Oncol. 1986, 6, 47-57. [PubMed]

90. Lupatini, A.L.; Colla, L.M.; Canan, C.; Colla, E. Potential application of microalga Spirulina platensis as a protein source. J. Sci. Food Agric. 2017, 97, 724-732. [CrossRef] [PubMed]

91. Galarza, V.O. Carbohydrates and proteins in microalgaes: Potential functional foods. Braz. J. Food Technol. 2019, 22, 2019043. [CrossRef]

92. Panahi, Y.; Darvishi, B.; Jowzi, N.; Beiraghdar, F.; Sahebkar, A. Chlorella vulgaris: A multifunctional dietary supplement with diverse medicinal properties. Curr. Pharm. Des. 2016, 22, 164-173. [CrossRef] [PubMed]

93. Shah, M.M.R.; Liang, Y.; Cheng, J.J.; Daroch, M. Astaxanthin-producing green microalga Haematococcus pluvialis: From single cell to high value commercial products. Front. Plant Sci. 2016, 7, 531. [CrossRef]

94. Hu, C.C.; Lin, J.T.; Lu, F.J.; Chou, F.P.; Yang, D.J. Determination of carotenoids in Dunaliella salina cultivated in Taiwan and antioxidant capacity of the algal carotenoid extract. Food Chem. 2008, 109, 439-446. [CrossRef]

95. Sikiru, A.B.; Arangasamy, A.; Alemede, I.C.; Guvvala, P.R.; Egena, S.S.A.; Ippala, J.R.; Bhatta, R. Chlorella vulgaris supplementation effects on performances, oxidative stress and antioxidant genes expression in liver and ovaries of New Zealand White rabbits. Heliyon 2019, 5, e02470. [CrossRef]

96. Madhumathi, M. Antioxidant status of Penaeus monodon fed with Dunaliella salina supplemented diet and resistance against WSSV. Int. J. Eng. Sci. Technol. 2011, 3, 1-14.

97. Sanhueza, J.; Nieto, S.; Valenzuela, A. Ácido docosahexaenoico (DHA), desarrollo cerebral, memoria y aprendizaje: La importancia de la suplementación Perinatal. Rev. Chil. Nutr. 2004, 31, 84-92. [CrossRef]

98. Qiu, C.; He, Y.; Huang, Z.; Qiu, W.; Huang, J.; Wang, M.; Chen, B. Biosafety evaluation of Nannochloropsis oculata and Schizochytrium sp. oils as novel human milk fat substitutes. Food Funct. 2021, 12, 2972-2984. [CrossRef] 
99. Zhang, L.S.; Chu, M.Y.; Zong, M.H.; Yang, J.G.; Lou, W.Y. Facile and green production of human milk fat substitute through Rhodococcus opacus fermentation. J. Agric. Food Chem. 2020, 68, 9368-9376. [CrossRef] [PubMed]

100. Boukid, F.; Rosell, C.M.; Rosene, S.; Bover-Cid, S.; Castellari, M. Non-animal proteins as cutting-edge ingredients to reformulate animal-free foodstuffs: Present status and future perspectives. Crit. Rev. Food Sci. Nutr. 2021, 27, 1-31. [CrossRef]

101. Matos, J.; Cardoso, C.; Bandarra, N.M.; Afonso, C. Microalgae as healthy ingredients for functional food: A review. Food Funct 2017, 8, 2672-2685. [CrossRef] [PubMed]

102. Lafarga, T.; Fernández-Sevilla, J.M.; González-López, C.; Acién-Fernández, F.G. Spirulina for the food and functional food industries. Food Res. Int. 2020, 137, 109356. [CrossRef]

103. Uribe-Wandurraga, Z.N.; Igual, M.; García-Segovia, P.; Martínez-Monzó, J. In vitro bioaccessibility of minerals from microalgaeenriched cookies. Food Funct. 2020, 11, 2186-2194. [CrossRef]

104. Javier, H.-B.; Vanegas, R.E. Potencial Biotecnológico de Microalgas en Zonas Aridas, 1st ed.; Servicio Nacional de Aprendizaje: Bogotá, Colombia, 2018.

105. Barkia, I.; Saari, N.; Manning, S.R. Microalgae for high-value products towards human health and nutrition. Mar. Drugs 2019, 17, 304. [CrossRef] [PubMed]

106. Novoveská, L.; Ross, M.E.; Stanley, M.S.; Pradelles, R.; Wasiolek, V.; Sassi, J.F. Microalgal carotenoids: A review of production, current markets, regulations, and future direction. Mar. Drugs 2019, 17, 640. [CrossRef]

107. Schreiber, C.; Schiedung, H.; Harrison, L.; Briese, C.; Ackermann, B.; Kant, J.; Schrey, S.D.; Hofmann, D.; Singh, D.; Ebenhöh, O.; et al. Evaluating potential of green alga Chlorella vulgaris to accumulate phosphorus and to fertilize nutrient-poor soil substrates for crop plants. J. Appl. Phycol. 2018, 30, 2827-2836. [CrossRef]

108. Karki, M.; Gibard, C.; Bhowmik, S.; Krishnamurthy, R. Nitrogenous derivatives of phosphorus and the origins of life: Plausible prebiotic phosphorylating agents in water. Life 2017, 7, 32. [CrossRef] [PubMed]

109. Toner, J.D.; Catling, D.C. A carbonate-rich lake solution to the phosphate problem of the origin of life. Proc. Natl. Acad. Sci. USA 2020, 117, 883-888. [CrossRef]

110. Pasek, M.A. Rethinking early Earth phosphorus geochemistry. Proc. Natl. Acad. Sci. USA 2008, 105, 853-858. [CrossRef] [PubMed]

111. Mau, L.; Kant, J.; Walker, R.; Kuchendorf, C.M.; Schrey, S.D.; Roessner, U.; Watt, M. Wheat can access phosphorus from algal biomass as quickly and continuously as from mineral fertilizer. Front. Plant Sci. 2021, 12, 631314. [CrossRef]

112. Kholssi, R.; Marks, E.A.N.; Miñón, J.; Montero, O.; Debdoubi, A.; Rad, C. Biofertilizing effect of Chlorella sorokiniana suspensions on wheat growth. J. Plant Growth Regul. 2019, 38, 644-649. [CrossRef]

113. Araujo Vidal, D.R.; Hernández Benítez, R.H.; Vanegas Guerrero, J. Efecto de la Inoculación de Cianobacterias en Cultivos de Interés Comercial en Zonas Semiáridas de la Guajira-Colombia. Rev. Colomb. Investig. Agroindust. 2018, 5, 20-31. [CrossRef]

114. Carrera, S.; Velasco, L.A.; Barreto-Hernández, A. Potential of benthic microalgae of the Caribbean sea as food in mariculture. Rev. Biol. Mar. Oceanogr. 2018, 53, 321-333. [CrossRef]

115. Grzesik, M.; Romanowska-Duda, Z.; Kalaji, H.M. Effectiveness of cyanobacteria and green algae in enhancing the photosynthetic performance and growth of willow (Salix viminalis L.) plants under limited synthetic fertilizers application. Photosynthetica 2017, 55, 510-521. [CrossRef]

116. Nayak, M.; Swain, D.K.; Sen, R. Strategic valorization of de-oiled microalgal biomass waste as biofertilizer for sustainable and improved agriculture of rice (Oryza sativa L.) crop. Sci. Total Environ. 2019, 682, 475-484. [CrossRef]

117. Rocca, S.; Agostini, A.; Giuntoli, J.; Marelli, L. Biofuels from Algae: Technology Options, Energy Balance and GHG Emissions; JRC98760; Publications Office of the European Union: Luxembourg, 2015.

118. Vacca Jimeno, V.A.; Angulo Mercado, E.R.; Puentes Ballesteros, D.M.; Torres Yépez, J.G.; Plaza Vega, M.E. Uso de la microalga Chlorella sp. viva en suspensión en la decoloración del agua residual de una empresa Textil/Using the microalgae Chlorella sp. live suspended in decoloration wastewater from a textile factory. Prospectiva 2017, 15, 93-99. [CrossRef]

119. Romero-Morales, M.A.; Ortiz-Villota, M.T.; Meza-Rodríguez, L.D. La biorremediación con microalgas (Spirulina máxima, Spirulina platensis y Chlorella vulgaris) como alternativa para tratar la eutrofización de la laguna de Ubaque, Colombia. Rev. Investig. Desarro Innov. 2018, 9, 163-176.

120. Gómez Santos, J.A.; Rodríguez González, L.G. Obtención de biomasa de microalgas en aguas residuales para la producción de biocombustibles. Renov. Rev. Estud. Interdiscip. Cienc. Soc. Tecnol. Innovació 2019, 3, 21-36.

121. Mora-Salguero, D.; Vives Florez, M.J.; Husserl Orjuela, J.; Fernández-Niño, M.; González Barrios, A.F. Evaluation of the phenol degradation capacity of microalgae-bacteria consortia from the bay of Cartagena, Colombia. TecnoLogicas 2019, 22, 149-158. [CrossRef]

122. Torres, D.D.; Cáceres Sepúlveda, S.; Roa, A.L.; Suárez Gelvez, J.H.; Urbina Suárez, N.A. Utilización de microalgas de la división Chlorophyta en el tratamiento biológico de drenajes ácidos de Minas de carbón. Rev. Colomb. Biotechnol. 2017, 19, 95-104. [CrossRef]

123. Muller-Feuga, A. Microalgae for aquaculture: The current global situation and future trends. In Handbook of Microalgal Culture: Applied Phycology and Biotechnology, 1st ed.; Wiley: New York, NY, USA, 2013; pp. 615-627.

124. Ramírez, B.D.G.; Valencia, J.U.S.; Arbelaez, A.F.A.; Herrera, J.M.; Rojano, B.A. Oxidative, sensory and fatty acid profile evaluation of a yogurt with docosahexaenoic acid (Dha) extracted from microalgae oil. Rev. Chil. Nutr. 2020, 47, 568-579.

125. Colorado Gómez, M.A.; Tirado, D.A.M. Economía de recursos naturales a partir de la producción de Spirulina (Arthrospira maxima) en fotobiorreactores, La Guajira, Colombia. Reto 2017, 5, 50-59. 
126. Oviedo-Montiel, H.D.; Herrera-Cruz, E.E.; Hoya-Florez, J.K.; Prieto-Guevara, M.J.; Estrada-Posada, A.L.; Yepes-Blandón, J.A. Crecimiento poblacional de Macrothrix spinosa alimentada con Chlorella sp. Orinoquia 2019, 23, 79-86. [CrossRef]

127. Torres-Valencia, G.A.; Imués-Figueroa, M.A.; Sanguino-Ortiz, W.R.; Chapman, F.A. Aislamiento de una cepa de rotiferos de agua dulce con potencial como alimento vivo en acuicultura. Rev. Investig. Pecu. 2018, 5, 25-32.

128. García Salazar, C.A.; Pérez Cardona, Y.A.; Ríos Osorio, L.A.; Múnera Porras, L.M. Efecto de un Consorcio de cianobacterias sobre la obtención de biomasa vegetal de la gulupa (Passiflora edulis f. edulis sims) bajo condiciones de campo en el municipio de Marinilla-Antioquia". Hechos Microbiológicos 2020, 11, 12-21. [CrossRef]

129. Ardila, Á.A.M.; López, M.Y.; Vásquez, C.M.E.; González, D.Á.D.; Barajas, S.A.F. Obtaining lipids and carbohydrates from microalgae via design of selective culture media. TecnoLógicas 2017, 20, 83.

130. Giraldo Calderón, N.D.; Díaz Bayona, K.C.; Atehortúa Garcés, L. Immobilization of the green microalga Botryococcus braunii in polyester wadding: Effect on biomass, fatty acids, and exopolysaccharide production. Biocatal. Agric. Biotechnol. 2018, 14, 80-87. [CrossRef]

131. Leal Medina, G.I.; Abril Bonett, J.E.; Martínez Gélvez, S.J.; Muñoz Peñaloza, Y.A.; Peñaranda Lizarazo, E.M.; Urbina Suárez, N.A. Producción de Ácidos Grasos Poliinsaturados a partir de Biomasa Microalgal en un Cultivo Heterotrófico. Rev. Ion 2017, 30, 91-103. [CrossRef]

132. Guarin-Villegas, E.; Remolina-Páez, L.; Bermúdez-Castro, J.; Mogollón-Londoño, S.; Contreras-Ropero, J.; García-Martínez, J. Effect of de Carbon/Nitrogen ratio on the production of microalgae-based carotenoids. Ing. Compet. 2020, $22,8686$.

133. Niño Castillo, C.M.; Rodríguez Rivera, F.C.; Díaz, L.E.; Lancheros Díaz, A.G. Evaluación de las condiciones de crecimiento celular para la producción de astaxantina a patir de la microalga Haematococcus pluvialis. Nova 2017, 15, 19. [CrossRef]

134. Miranda, A.M.; Ossa, E.A.; Vargas, G.J.; Sáez, A.A. Efecto de las Bajas Concentraciones de Nitratos y Fosfatos sobre la Acumulación de Astaxantina en Haematococcus pluvialis UTEX 2505. Inf. Tecnol. 2019, 30, 23-32. [CrossRef] 